\title{
A Palace with a View: Imagining Europe in the Baroque City[1]
}

MARKUS REISENLEITNER

Let me begin with an exercise in the kind of self-positioning mandatory for post-linguistic-turn humanists. I grew up in a number of places, but a very formative one (at least retrospectively, but how else?) was the third district in the city of Vienna, which since 1918 has been the capital city of the Republic of Austria and before that served as the residence of the Habsburg imperial court since 1519/1526 (permanently since 1619). This centrally located district - southeast of the Ring in the direction of the southern train station - is fairly densely populated (I say fairly because having lived in Hong Kong taught me the relativity of urban density). It is an urban environment characterized by predominantly late-nineteenth century apartment buildings and a substantial migrant population from both ends of the social spectrum: diplomats working at the UN and in the many embassies concentrated in this district as well as a substantial population of blue-collar workers from Turkey and the former Yugoslavia. Despite the predominantly modern fabric of this part of the city, the nearest, somewhat unlikely "playground" of my childhood years was the garden of the Belvedere, a Baroque palace built at the beginning of the eighteenth century $(1714-1716 ; 1721-1723)$ by Lucas von Hildebrandt for Prince Eugene of Savoy, a nobleman who had joined the Habsburg army, proved his mettle during the Ottoman siege of Vienna in 1683, and successfully masterminded the ensuing military campaigns against both the French and the Ottomans, campaigns which resulted in the Habsburg's successful re-conquest and subsequent colonization of a large part of eastern Central Europe and the Balkans. As one of the foremost members of the court of the "Baroque" Habsburg emperor Leopold I, the rival of the French Sun King, Prince Eugene also 
became one of the largest landowners in the expanding and booming early modern city.

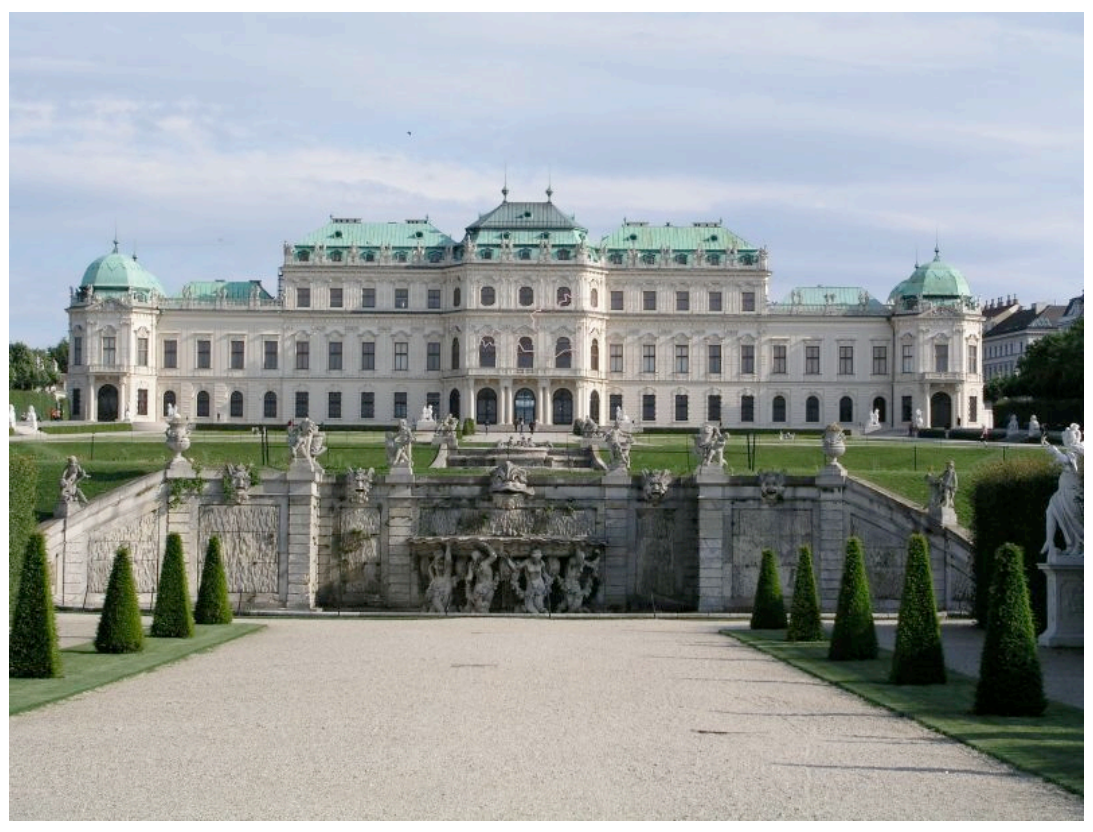

The Belvedere consists of two separate Baroque structures on the lower and upper ends of an incline ascending one of Vienna's four terraces, connected by a formal Baroque garden. Each of the two structures houses a separate collection of Austria's National Gallery: the Lower Belvedere the Museum of Medieval Art and the Baroque Museum, and the Upper Belvedere the collections of the nineteenth and twentieth centuries.

Frequently, Saturday outings during my childhood would consist of my parents taking me to the permanent collections or special exhibitions in either of the two galleries, followed by a stroll through the garden, which, in my childhood memory, was a place of freedom of movement, very different from the scripted progression and sequential locomotion of the museum space, which, these being very traditional collections, revealed the masterpieces of art history (or at least those in the legitimate or illegitimate possession of the Republic of Austria), not through the Baroque sense of wonder, curiosity and totality or the romantic immediacy of aura, but by what Philip Fisher has called the "technology of the series" (Fisher 7; cf. Bennett), in Tony Bennett's turn of phrase "works of art placed one after another in a sequential toil that is historicized" (Bennett 44). And my personal memory is certainly one of 
toil. The garden, on the other hand, allowed for more child-friendly activities, like running circles around the guide-book toting German tourists, marveling at American college students who could not take their paws off the sphinxes' naked breasts, and, during the winter, to picking icicles from the numerous fountains that had frozen over in their own subversion of the regulated flows of Baroque engineering ingenuity.

As everybody who has ever tried to debate large-scale building or renovation projects of historical substance with local communities knows, spaces derive part of their strong affective quality from those intangible qualities that situate life stories and continue to impose their own meanings, manifest or spectral, thus becoming potent identity markers. Doubtless my interest in the cultural history of spaces has been influenced by an early exposure to manifestations of history, manifestations which held, and still hold, a specific significance for me, and if I were asked to explain my later research and teaching trajectory, I could probably at least partly explain my continuous and ongoing straddling of the chronological divider of modernity with the metaphor of my childhood movement in my formative years between the Lower and Upper Palaces of the Belvedere, the Medieval/Baroque and the Modern (and finding freedom in the space in-between). However, for all of us: the layers of history in our built environment frame life stories, and remembering them through the prism of everyday histories produces cultural meanings and identities that matter.

They also produce meanings that can be quite misguided. As I would later find out, and teach, Baroque gardens and parks, with their deliberate subjugation of nature into the language of architectural form, are, of course, anything but intimations of freedom, spontaneity and the quest for personal self-actualization, and were most certainly not designed in any kind of juxtaposition to well-ordered interior spaces. Social and cultural history, having learned the "never-again" lesson of the discipline's easy co-optation by the Third Reich and having come to be understood at least since the heady post-1968 days as a politically aware, emancipatory quest for uncovering the roots of totalitarian structures and regimes of power, has taught us historians to situate individual micro-narratives (our own as well as those of others) in a wider framework of the social and material foundations of culture. And Baroque architecture's spectacle of power, often, and definitely in the case of the Belvedere, forged into the agendas of the nation-state, can indeed serve as a prime example of continuing to provide, in de Certeau's sense, a theatre of shared meanings for imagined communities, 
founding myths that prevail over the fissures between past and present as well as the more obvious social divisions (Reisenleitner "Wege Zum Adel" 32).

But meanings seldom remain uncontested. Interpreting contestations, even minor ones like the childhood narrative above, in Stuart Hall's sense as negotiated or deviant readings, or as the tactics, momentary disruptions to the coercive power of strategic structures, which characterize de Certeau's practices of everyday life, seems to me, while not inadequate as an explanatory framework, to be lacking or at best underexposing the two dimensions that I have become most interested in: the historical and the spatial. In zooming out, as it were, from the Belvedere, and re-situating Baroque spatial practices, and how they survive, as public urban landscapes in their urban context and environment, rather than approaching them as what Donald Horne called "great museums" (Horne), I hope here to add to the understanding of why such spaces matter, and how they might matter differently, particularly in the contested context of a culturally defined European space. While my quest may be motivated by the elusive meaning of the slippery icicles of my childhood memories, it should ultimately demonstrate how history can be practiced as a contextual cultural critique (and that cultural studies approaches have something to say about the early modern period).

Beginning, then, with a close-up: The Belvedere is generally considered a "masterpiece" of Baroque architecture, and its architect Lucas von Hildebrandt is mentioned alongside Bernini and Fischer von Erlach. It was built during the later stages of a Baroque building boom that had started a century earlier in many European court centers (Reisenleitner "Habsburgische Höfe in der Frühen Neuzeit" 107) and accompanied the wider transformation of social relationships in many parts of Europe described as the rise of absolutism. In the Habsburg lands, the decisive event that, symbolically and politically, condenses this structural transformation into a metonymic watershed and can serve, in its epic repetition, as a guise for an explanation, is the battle of the White Mountain/Bilá Hora in 1620, a two-hour long military encounter which marked the culmination of a century-long power struggle between a (at that point overwhelmingly Protestant) territorial nobility and the endeavors of the Habsburg dynasty to stabilize politically their motley collection of inherited, unruly, and besieged lands. A decisive military victory of the Habsburg loyalists, the event accelerated an already quite militant Catholic counterreformation and 
triggered sweeping reforms in the administration of the territories, reforms which amounted to a rationalization and centralization of state power around the court centre in Vienna, which in turn prompted Vienna's rise to a major cultural and political (albeit not economic) center during the Baroque period.

Next let's consider the various ways the history of this battle has and can be written. What for Czech historiographers ushered in the "dark ages" - the effective loss of territorial self-administration of the estates of the Bohemian kingdom -, in the hegemonic Western tradition, is more often characterized as the period of "Austria's rise to great power." This is the rhetoric of a historiography whose nineteenthcentury founding principles pointed its guild members towards constitutional issues and the reification of the nation state. The move towards absolutist rule during the seventeenth century, described as "modernization" in the inexorable teleology of national historiography, could easily be framed as the dynastic, incomplete precursor of what was reified as a quasi-natural polity. As in France, where the courts of the Bourbons were "thought to have consolidated 'national' state building by allowing the 'absolute' rulers to overcome 'feudal' opposition" (Duindam 7), the Habsburgs were credited with state building and overcoming the "fragmentation" of state power during the feudal age, which had aggregated many rights, and the accompanying privileges, in seigneurial domains (Herrschaften). The fact that, unlike in the French situation, there was no twentieth-century successor state to the Habsburg empire did little to prevent historians from framing the narrative of state building along similar lines, au contraire. "Everywhere, the ideals of national state building dictated the interpretation of dynastic Europe" (Duindam 7), and only recently the European Science Foundation launched a project along similar lines, searching for the "Origins of the Modern State in Europe" in absolutist structures of the early modern period (Patrouch).

Post-1968 social historians, on the other hand, hearken back to different, yet often equally totalizing constructions, most popular among them Norbert Elias's remarkably encompassing framework of "civilization theory." In his sweeping narrative of a transformation of manners in what he describes as the process of civilization - the shift from external force (Fremdzwang) to internalized standards of behavior (Selbstzwang) -, Elias chose the courts as the stage, the nobles as protagonists. "Only by losing its power could the nobility set the standards for 'civilization' in Europe. Elias' conceptual framework thus 
neatly fitted the perspective of the 'national' historians: again we learn that the court was important because it contributed to the rise of the modern state by annulling the power of that other atavism: nobility" (Duindam 8). That "[ $t]$ he quintessence [of the Baroque] is discipline, limitation, the principle of concentration and integration" is something the art historian Arnold Hauser already synthesized in 1951 (Hauser II/178), and following in his footsteps, the rediscovery of Elias during the 1970s went well with critical approaches that focused on the emergence of modern control mechanisms, the wider debate around social discipline and governmentality that served as a general framework for explaining the nexus between state power, culture, society, and religion in the early modern period.

It does not seem productive to delve any more deeply into the by now somewhat dated debate about the justification of basic concepts like absolutism (recently re-dubbed the "coordinating state" (MacHardy) and social discipline during that time.[2] As so often in history, what was a messy, complex and uneven process has tended to be simplified, sometimes beyond recognition, by attempts to synthesize, generalize and abstract. Kings and emperors were sometimes weak, the Habsburg coffers certainly permanently empty, and the nobles whose surviving letters I've read in Bohemian and Austrian archives spent as much, or more, time on their country estates than at the imperial court in Vienna, passing their time with trivialities, amorous affairs, and writing very long-winded letters that reveal surprisingly little. But this is not what Baroque architectural grandeur in the expanding court centers, the stage for absolutism triumphans, visibly remembers.

Thus, and now we have to zoom a bit more back in order to capture another perspective, the absolutist narrative can be told as a story of the transformation of urban spaces. Leonardo Benevolo has attempted to do this in his monumental synthesis of European urban history, which details how:

During the building boom of the late sixteenth and early seventeenth centuries, European sovereigns sponsored numerous projects that brought symmetry and regularity to the large cities... [because] Absolutism demanded perfect and unquestioned settings... (130). Functional disorder was disguised by the structural façades; daily events were lost in the vast external and internal spaces. Visual decorum stood in conscious opposition to these occurrences, presenting a conventional image of regality and prestige which would endure as exemplary models through time and space. (145) The demand for geometric regularity encountered a network of urban settlements dating from the late Middle Ages and only partially capable of modification. It was in the great not 
yet urbanized settings that perspective design enjoyed its boldest application. Out of these tensions derived the tension and prominence of its greatest productions: the world of Versailles closed within an artificial horizon..., the carefully spaced setting of water, parks and monuments under the arctic sky of St Petersburg. (Benevolo 150f)

In this narrative, the symbolic representation of a cosmological order was subsequently imitated by the noble courtiers, and the symbolic language of the imperial centre contributed to the substantiation of a hierarchically structured, divinely legitimated, and architecturally articulated spectacle of power and discipline that pervaded every aspect of life, from the ritualized patterns manifested in elaborately staged entries, weddings, tournaments, fireworks, and other festivities that leveled any distinction between stage actors and audience, to the dancelike movements and gestures regulated by the elaborate semiotic systems of court ceremonials. The state as a stage: As Peter Burke has regularly been reminding us for the past two decades, this concept is not a Foucauldian theorem, but quite familiar to the contemporaries of Louis XIV (Burke 7). As in Clifford Geertz's Bali of the nineteenth century, the stage served for "the public dramatization of ... social inequality and status pride. It was a theatre state in which the kings and princes were the impresarios, the priests the directors, and the peasants the supporting cast, stage crew, and audience" (Geertz 13; quoted in Burke 12). Situating Baroque architecture and early-modern dynastic power in its founding moment of the social can certainly be linked to the echoes of the cultural expressions of absolutism appropriated by nation-states. Examples are not hard to find, Versailles being the most often quoted, but let me return to the Belvedere by way of illustration.

This particular palace's status as a powerful site of memory for a nation-state whose lineage and continuity to its early modern predecessor is more than strained was reaffirmed last year by an exhibition in the Upper Palace entitled "Das Neue Österreich" (The New Austria), which celebrated the fiftieth anniversary of the country's neutral geopolitical status (in the construction of the post-war imagined community inextricably intertwined with the end of allied occupation). The obvious reference to the past for the event was the signing of the treaty in 1955 in the Belvedere, but the signing itself hearkens back to a much longer tradition of appropriation for purposes of state-building. Prince Eugene was a formidable ally for the Habsburgs in strengthening their dynastic rule, but the Belvedere's later history is even more significant. The palace was acquired by the Habsburgs from the heirs of 
Prince Eugene in 1752, and a significant part of the dynasty's art collection, the "Imperial and Royal Picture Gallery," was transferred from the imperial castle (the Hofburg, 1776) and opened to the public in 1781. As elsewhere in Europe, "[t]he objects they contained then assumed the function of embodying a representative publicness of and for the power of the king. This was what royal art galleries made visible: addressing their visitors as subjects" (Bennett 36).[3] Other collections followed. At the end of the nineteenth century, the palace became the residence of the Archduke Franz Ferdinand; in 1918 it passed into the possession of the newly founded Republic. In the sequence of these events, the transition from absolutism to modern nation-building in the Habsburg lands is not a significant period break, but rather an almost imperceptible shift in emphasis. What survives from the Baroque has come to serve as the material embodiment for framing the commonality of an imagined community, a sense of national history (Bennett 136), now commodified into "the new leisure worlds of heritage culture with their projection of a common and shared inheritance, available to all for the price of a ticket or a Sunday outing" (Corner and Harvey 11).

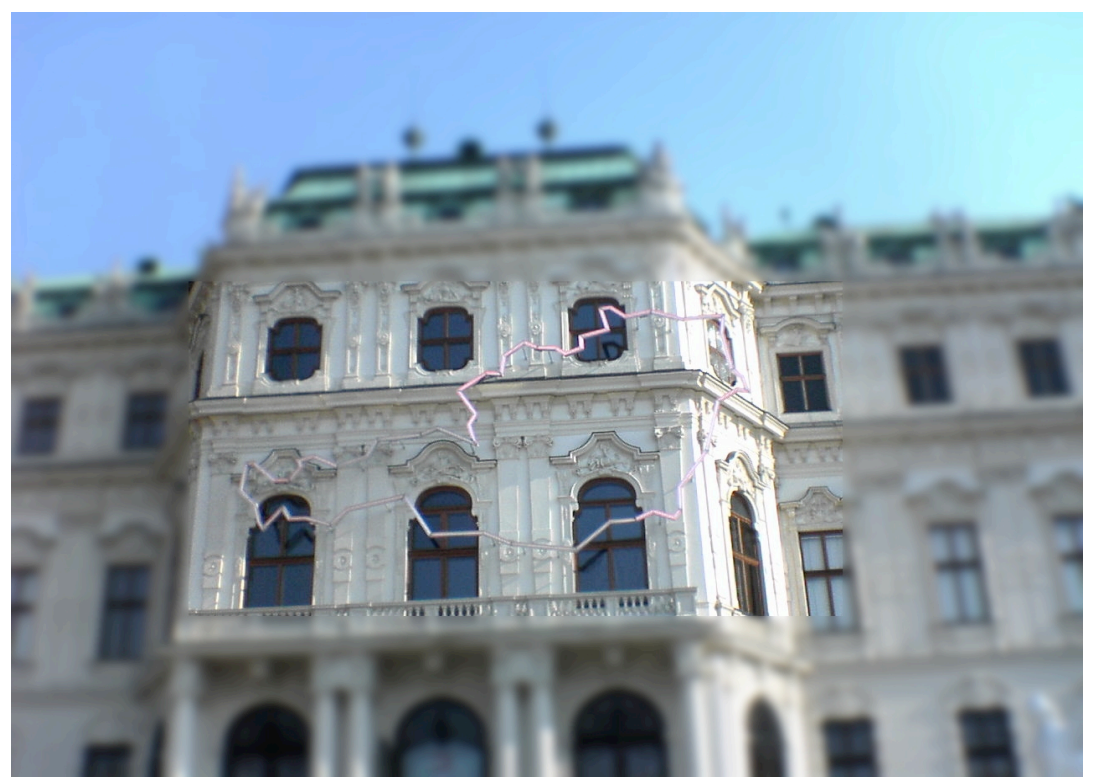

Sometimes, however, things go horribly wrong, and the fissures of history become glaringly obvious. The Belvedere has recently made headlines in the world news when, after a prolonged legal battle, a court 
ordered Austria to return five paintings by Gustav Klimt expropriated during the Nazi era and now prominently on display in the Upper Belvedere to their rightful owner, the heirs of a Jewish family forced to flee the country. That the Austrian government has been able to maintain a morally objectionable, diplomatically embarrassing, and legally clearly untenable position for so many years - a very expensive position at that - can certainly be linked to an implicit desire to sustain the symbolic power of the Belvedere collection at all costs, a collection which has become a powerful lieu de mémoire, with paintings that qualify as "national treasures" and enforce a historical continuity between the Baroque building, the sparks of modernism during the waning of the empire, and the present republic - notwithstanding the irony that fin-de-siècle art has only qualified for this rarefied status since the profound re-evaluation of Vienna as the cradle of modernity during the early 1980s. The paintings in question had until the mid1990s been hung in a rather inaccessible attic of the gallery - if I took my students there, I had to make sure no more than 10 people were in the attic at any one time because of the dilapidated state of the floor-and they were only moved to a prominent location shortly before the lawsuit was filed. After the lawsuit, however, the paintings were firmly established in the Austrian national imaginary, with billboards showing them (illuminated) in every bus station of the city.[4]

Even if artifacts do not often expose the violence of their provenance so clearly, their appropriation for imagining the nation is clearly ideological in their de-contextualization of historical artifacts, obscuring of social divisiveness, construction of imaginary historical continuities, camouflage of the material aspects of place-competition, and, in a worst case scenario, creation of themed environments. Critical voices maintain that such forms of recuperation "construct landscapes and fill them with meaning. In turn the constructed landscape exerts power by naturalizing and reifying social realities." (Horst 176) The demystification process that traces Baroque culture, its effects and appropriations, to the predominant processes of social and individual transformation in European societies of the early modern period is clearly a very important task, crucial in order to recognize the processes constructing the enforced political cohesion of identity projects built around official sites of memory. An emancipatory approach to cultural history needs to engage precisely with those lineages and continuities and to hone the skills necessary to decode all these processes of multiple and broken lines of identity homogenized into the coherent framework 
of interpretation a site of memory is trying to generate so that one can spot anachronisms, at least the more blatant ones. Demystifying cultural processes that obscure injustices of the present and the violence of the past is a crucial moment in the humanities both as a professional research practice and a pedagogy.

Such an interpretive method also has an impact on how we imagine - and imposes limits on how we are able to imagine - Europe's urban spaces in their historical and spatial dimensions. Representing Baroque urbanity as an outcome of the deliberate acts of the dynastic rulers and their entourage, who used them as metaphors or stages for their selfpresentation of territorial consolidation clearly perpetuates intentional self-assertions of the absolutist system (Burke; Vocelka Die Politische Propaganda Kaiser Rudolfs II.), whether regarded, somewhat anachronistically, as propaganda or glorification (on this methodological aspect see Burke 5), but, more importantly, it imagines the history of European urbanity in the Baroque as pre-structured by nations "in the making," a direct outcome of a heuristic device that ultimately reduces material cultural manifestations to their origin in "the social" (a social inextricably intertwined with a spatial imaginary itself structured by the nation state.) That implies (and this is by all means, I would argue, a theoretical problem common to cultural history and cultural studies) that contestations of those meanings must also be derived from the social. In order to avoid the predictability of onedimensional approaches mesmerized by the social, I would suggest that we, in Edward Soja's words, "put cities first" (Soja) and take another look at the histories urban space generates. Cultural geographer Steve Pile reminds us that "... the city cannot be thought of as having one geography and one history" (Pile, Brook and Mooney vii), but needs to be seen as a shifting, unstable terrain constantly arranged and rearranged in the progression of its diverse and contingent formations that continue to manifest themselves in the urban morphology. The result is a machine, not of living, but of meaning creation that does not seem to allow the ultimate containment of territorialization or of a decisive way of governance, and these are the processes a spatial/historical approach to Europe needs to attend to.

This implies inserting a wedge into the smooth transition between the stage of imperial power in the Baroque and an urban space that is metonymically appropriated to represent the nation in identity projects, an (as a matter of fact very modern) understanding of urban morphology as a "mirror of authority and decisive act of governing" 
(Corbusier viii). Not because cities, as Benevolo claims, "begot that region, historically defining European civilization and continuing to be its most salient characteristic" (Benevolo xv) and are therefore somehow essentially European (nothing is), or somehow more European than dynasties or nation states (how does one compare European-ness anyway?) but precisely because such a move can direct our attention to spatial/historical processes that define Europe in ways not prestructured by the nation-state paradigm that Baroque propaganda architecture helped create, tried to impose, and is so often perpetuated in its more recent national appropriations.

Back to our case study. The Belvedere is, as I described earlier, not located in the medieval center of the city, but between an inner and an outer ring of fortifications, a division which continues to structure the city and coincides with different levels of elevation. But these are not the only divisions that persist.

In the wider context of counter-reformatory absolutism, popular culture practices were transformed, their carnevalesque and subversive elements disciplined, and a privileged space carved out for an elite culture based on representation and glorification, rather than subversion and topsy-turvy worlds of inversion and randomness. Not surprisingly, this disciplining also has an urban aspect. In Vienna, the distinction and contest between high culture and popular culture has convincingly been linked to the dichotomy between the inner city and what is often rather inadequately translated as suburb (Vorstadt) (Horak Metropole Wien; Horak Stadt. Masse. Raum; Maderthaner and Musner). The Belvedere's location in the urban fabric, thus constitutes, like other Baroque palaces', literally and metaphorically, a spearhead of high culture, a strategic location for being co-opted for the gallery that articulates the GrecoRoman heritage and the Christian, or rather Catholic, cosmology on which Baroque art was founded into a high culture idiom common to European courts but increasingly interpreted as national heritage for the formation of a national canon.[5] Wedged in-between the center and the suburb, the palace's location within the urban fabric reveals semantic tensions inadequately described by the "stage" metaphor. It points us towards the historical encounters and struggles that went into its making, between high and low, between external representation and internal state building. If we pay attention to it, we can identify the visible fault line between high and low in urban encounters where cultural and social stratification mechanisms intersect with the spatial 
dimensions of the internationalism of the high and the localism of the low.

The maybe more obvious fault-line that the location of the palace between two rings of former fortifications reminds us of is the hostile confrontation with the Ottoman empire whose mythological commemoration established Vienna as a bulwark of a Christian Europe against Islam (Vocelka "Wien zwischen Grenzfestung und Residenzstadt") and on whose spoils the palace of the Türkensieger, was built (in another turn of popular memory's misguided historical continuity, which works to elide the difference between the Ottoman Empire and the present-day Turkish nation state). The walls are gone now, but we do not need the bird's eye view of modern technology, i.e. Google, to appreciate the continuing presence of spatial divisions of the early modern city in the urban fabric of the present. What used to be two lines of defense are now major ring roads, the Ring and the Gürtel, funneling traffic flows which perpetuate the spatiality of the early modern city 150 years after the fortifications were razed.

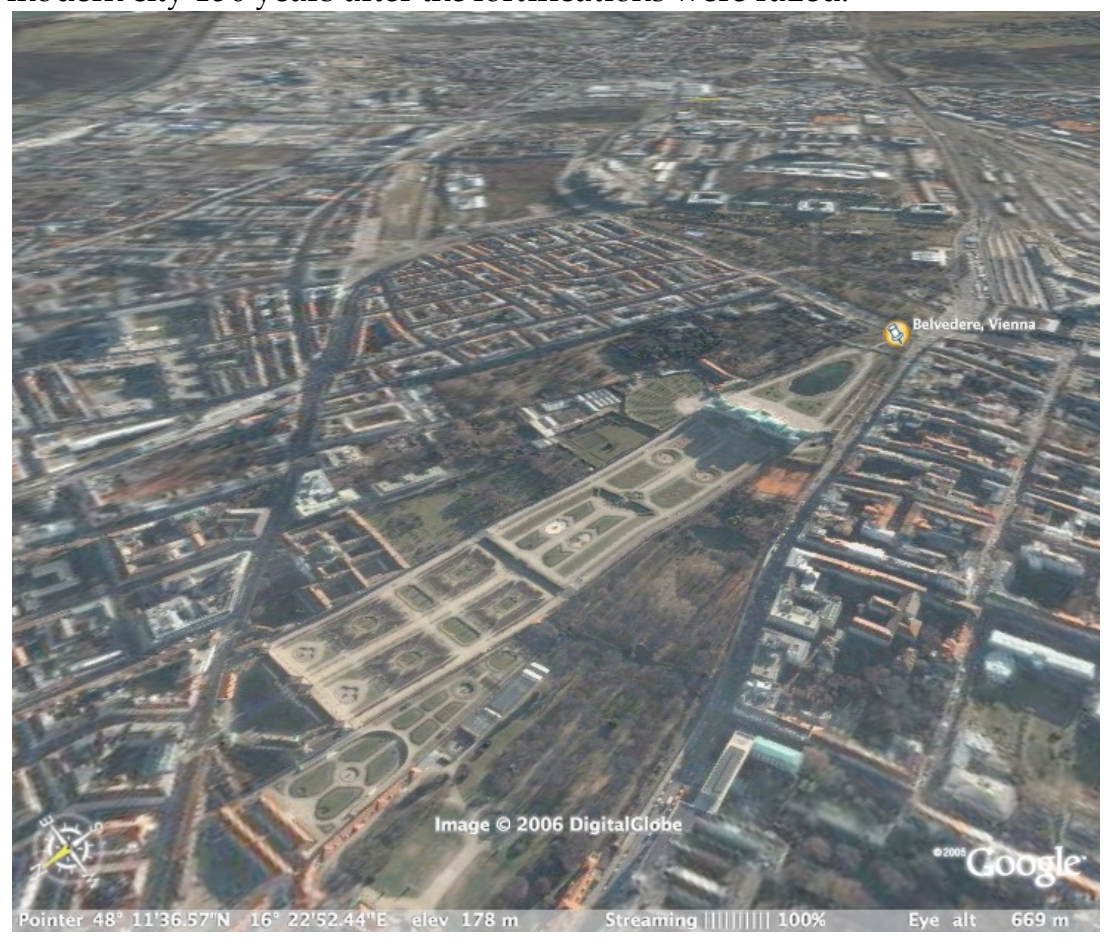

Histories of violent conflict with the Ottomans are thus remembered very differently from a kind of warfare which was equally bloody, yet 
culturally diametrically opposed: the confrontation with France, which set the tone for the transformation of Vienna in the sixteenth and seventeenth centuries and was stylistically formative for the Belvedere, and is still present in the visibility of the Belvedere's façade.

The longevity of cultural imaginaries that perpetuate the dichotomy of an imaginary cultural difference based on a common "European" heritage (France) and a difference imagined as more fundamentally opposed and irreconcilable, as the motivation for erecting walls is not only obvious but of great current relevance (Turkey). I am interested in how the European history of territorial conflicts and expansion has indelibly marked early modern urbanity as a contact zone of an imperialist world system in its initial stages as the flip side of the European nation-building process. When Peter Burke mentions almost as a footnote that Louis XIV received "homage from the nations of the world, including 'Siamese, Tonkinese, Algerians, Chinese, Iroquis'" (Burke 160. This quote seems almost like the premonition of a world system that connects China and Canada!), this is a very different story from the story of absolutism characterized by consolidation, rationalization and progressing internal order whose mis-en-scène is the Baroque city as a stage. "[C]ontestatory expressions from the site of imperial intervention [have] long [been] ignored in the metropolis" (Pratt 2). As Anthony King has demonstrated in other contexts and for a later period (A. D. King Urbanism, Colonialism, and the World-Economy; A. D. King Global Cities), the meeting/el encuentro (Massey, Allen and Pile 102) inscribes itself into the urban.

Yet processes of inscription can also be processes of erasure (Klein). What cemented the Ottoman's alterity vis-à-vis a Europe conceived of as Christian and buttressed the move of Habsburg expansion into their territories, also produced the "liberation" of parts of southeast Europe. The Belvedere is located between the southern train station that used to connect the capital with its periphery in the southeast and a major traffic artery that points us towards southeastern Europe, and in the city's memory the street where "the Balkan begins," a territory imaginarily assimilated into the city in another denial of the violence of a historical process and a first step towards the cultural and political invisibility of Vienna's largest migrant population from the former Yugoslavia (Fischer "Representing Migrants from Southeastern Europe in Vienna"; Fischer "Migrant Voices in Vienna's Contemporary History"). This has been the site of arrival and departure of migrant workers from (former) Yugoslavia since the 70s, when a whole village of Yugoslav shops 
existed in its vicinity, and signs in Croatian directed migrants to the facilities in the train station. Now it is very hard to find signs in either Serbian or Croatian in Vienna, but its native speakers are still there.

James Clifford pointed out that "the currency of culture and identity as performative acts can be traced to their articulation of homelands, safe spaces where the traffic across borders can be controlled. Such acts of control, maintaining coherent insides and outsides, are always tactical. Cultural action, the making and remaking of identities, takes place in the contact zones, along the policed and transgressive intercultural frontiers of nations, peoples, locales. Stasis and purity are asserted - creatively and violently - against historical forces of movement and contamination" (Clifford 7). The European city has been a crucial contact zone, and, as has been argued here, its Baroque layer (but of course not only this one) has the potential to mobilize its spatial and historical meanings. Recovering these meanings is crucial for reimagining the structuring processes of European spaces of identity, beyond national paradigms and their antecedents, as contingent and multiple encounters of translation and hybridization policed and purged by a desire for Heimat.

These narratives of the Baroque city in Europe are obviously not incompatible with, or contradictory to, a governmental narrative. But I would insist that what putting cities first generates is not a postmodern move away from a master narrative by adding some other little narratives to it. If we look not only for the hidden or manifest social agenda in the urban morphology, but rather for the historical operations of the urban itself, if we imagine the urban fabric at any one moment as a historically saturated present, a temporal heterogeneity in which cities act as semiotic reservoirs whose (in Scott Lash's word) "intensities" have a propensity to be mobilized, and whose memory work can indicate potentials for the future by continuously making it possible to re-imagine the past. "[S]aturating with detail an articulated place and point in time, a critical reading can extract from its objects a parable of practice that converts them into models with a past and a potential for reuse, thus inspiring to invest them with a future.," muses Meaghan Morris (Morris 3). The very ephemerality of the urban present, Ackbar Abbas's deja disparu, is precisely what situates the urban in "struggles over meaning and value of history in the present, where "the present" is assumed to have temporal depth" (Morris).

The Belvedere's walls remember much more than the Baroque spectacle of power. Their place in the urban fabric relates them to lived 
historical experiences. For the French diplomats whose embassy is around the corner, they remember a history of rivalries, more often than not violent, framed by a shared culture of representation. For the Southern Slavs who live up the hill, in what used to be the Vorstadt, they remember a history of colonization and forced assimilation. For the Turks led by the contingencies of historical and geopolitical processes to work as cleaners in the apartment buildings on either side of its walls, they remember a history of conquest. For the Jews whose portraits have become "Austrian masterpieces," they remember a history of erasure. And so on.

Cui bono? Readjusting our lenses, as it were, is not merely a way of producing more adequate knowledge of the past academically, although this is certainly a good enough reason. But the way we imagine a past matters beyond this. Reclaiming the semiotic reservoir of the urban as memory, as "a text to be deciphered, not a lost reality to be rediscovered" (N. King 62) is an act of political intervention, a practice of uncovering the erased, the forgotten and the marginalized, designed to "'lend a voice' to silent symbols or 'dispel familiarity' in the case of familiar symbols, and therefore intervene in the status and configuration of the framework of contemporary memory by highlighting less familiar places of memory and tempering the emotional appeal of more familiar places." (Carrier 51). In this sense the past may be a foreign country, but one well worth visiting.

Listening to the submerged stories is the first step. "Connecting the stories to reclaim the landscape as people's history is the next" (Hayden 245 ) - not in the form of historiography as a political identity project; but as a historic detournement, a contribution to the multiple voices that have been defining the European urban experience beyond its nations. The Belvedere can do it. Versailles can do it. Vienna can do it. Paris can do it. Europe can do it. That's what I have been doing and want to continue to do: Re-imagine urban culture as a construction site of histories, as it were, in order to lay a basis for re-thinking how all too stroppy strangers can live together in cities without doing each other, or themselves, too much violence.[6]

NOTES

[1] This article is based on a paper given at York University in February 2006. I gratefully acknowledge comments and feedback from colleagues received on this occasion. I am also grateful to Wladimir Fischer for commenting on the paper and 
providing valuable additional information on the history of migration from the former Yugoslavia to Vienna.

[2] Doubtless from a different perspective, early modern state building is equally based on the complicity and compromise with the nobility, perpetuating a feudalist system of surplus appropriation buttressed by a superstructure that sustains extra-economic coercion in the relations of production, and the conditions vary greatly even between such model nations of state-building, France and the Habsburg lands, while many of the rights concentrated in the seigneurial domain are only gradually acceded to the state, a process not complete until well into the nineteenth century.

[3] Tony Bennett maintains that the Republic now makes manifest the nation as the state, rather than nation as the king's realm; I am not sure this distinction is meaningful, seeing as the state was very much the king's realm as well under the conditions of absolutism.

[4] I owe this information to Wladimir Fischer.

[5] This synthesis had of course already occurred during the Renaissance, but the Baroque transformation of the court granted it much higher visibility.

[6] I owe this brilliant turn of phrase to James Donald.

\section{WORKS CITED}

Benevolo, Leonardo. The European City. Making of Europe. Oxford, UK; Cambridge, Mass.: Blackwell, 1993.

Bennett, Tony. The Birth of the Museum: History, Theory, Politics. London; New York: Routledge, 1995.

Burke, Peter. The Fabrication of Louis XIV. New Haven: Yale University Press, 1992.

Carrier, Peter. "Places, Politics, and the Archiving of Contemporary Mermory." Memory and Methodology. Ed. Susannah Radstone. Oxford: Berg, 2000. 37-57.

Clifford, James. Routes: Travel and Translation in the Late Twentieth Century. Cambridge, MA; London: Harvard University Press, 1997.

Corbusier, Le. The City of Tomorrow and Its Planning. Urbanisme (1927). Trans. Frederick Etchells. London: Architectrual Press, 1947.

Corner, John, and Sylvia Harvey, eds. Enterprise and Heritage: Crosscurrents of National Culture. London; New York: Routledge, 1991.

Donald, James. Imagining the Modern City. Minneapolis: University of Minnesota Press, 1999.

Duindam, Jeroen Frans Jozef. Vienna and Versailles: The Courts of Europe's Dynastic Rivals, 1550-1780. New Studies in European History. Cambridge, U.K.; New York: Cambridge University Press, 2003.

Fischer, Wladimir. "An Innovative Historiographic Strategy. Representing Migrants from Southeastern Europe in Vienna." Enlarging European Memory: Migration Movements in Historical Perspective. Eds. Mareike König and Reiner Ohlinger. Stuttgart: Thorbecke, 2006.

---. "Migrant Voices in Vienna's Contemporary History." Historical Urban Studies. Eds. Cynthia Brown and Richard G. Rogers. Aldershot: Ashgate, forthcoming.

Fisher, Philip. Making and Effacing Art: Modern American Art in a Culture of Museums. New York: Oxford University Press, 1991. 
Geertz, Clifford. Negara: The Theatre State in Nineteenth-Century Bali. Princeton, N.J.: Princeton University Press, 1980.

Hauser, Arnold. The Social History of Art. 4 vols. London: Routledge \& K. Paul, 1962.

Hayden, Dolores. The Power of Place: Urban Landscapes as Public History. Cambridge, Mass.: MIT Press, 1995.

Horak, Roman et al. Metropole Wien: Texturen der Moderne. Wiener Vorlesungen, Konversatorien Und Studien; Bd. 9. 2 vols. Wien: WUV, 2000.

---. Stadt. Masse. Raum: Wiener Studien zur Archäologie des Popularen. KulturWissenschaft; Bd. 2. Wien: Turia + Kant, 2001.

Horne, Donald. The Great Museum: The Re-Presentation of History. London: Pluto Press, 1984.

Horst, Hilje van der. "Multicultural Theming: Pacifying, Essentializing and Revanchist Effets." Placing History: Themed Environments, Urban Consumption and the Public Entertainment Sphere. Eds. Susan Ingram and Markus Reisenleitner. Vienna: Turia\&Kant, 2003. 175-200.

King, Anthony D. Global Cities: Post-Imperialism and the Internationalization of London. International Library of Sociology (London). London; New York: Routledge, 1990.

---. Urbanism, Colonialism, and the World-Economy: Cultural and Spatial Foundations of the World Urban System. International Library of Sociology. London; New York: Routledge, 1990.

King, Nicola. "Autobiography as Cultural Memory: Three Case Studies." New Formations 30.Winter 1996 (1997): 50-62.

Klein, Norman M. The History of Forgetting: Los Angeles and the Erasure of Memory. London; New York: Verso, 1998.

MacHardy, Karin Jutta. War, Religion and Court Patronage in Habsburg Austria: The Social and Cultural Dimensions of Political Interaction, 1521-1622. Basingstoke, Hampshire; New York: Palgrave Macmillan, 2003.

Maderthaner, Wolfgang, and Lutz Musner. Die Anarchie der Vorstadt: Das andere Wien um 1900. 2. Aufl. ed. Frankfurt [am Main]; New York: Campus, 2000.

Massey, Doreen B., John Allen, and Steve Pile, eds. City Worlds. London; New York: Routledge in association with The Open University, 1999.

Morris, Meaghan. Too Soon Too Late: History in Popular Culture. Theories of Contemporary Culture; V. 22. Bloomington: Indiana University Press, 1998.

Patrouch, Joseph. "Review of Karin J. MacHardy, War, Religion and Court Patronage in Habsburg Austria: The Social and Cultural Dimensions of Political Interaction, 15211622." HABSBURG, H-Net Reviews August (2004).

Pile, Steve, Christopher Brook, and Gerry Mooney, eds. Unruly Cities? Order/Disorder. London and New York: Routledge, 1999.

Pratt, Mary Louise. Imperial Eyes: Travel Writing and Transculturation. London; New York: Routledge, 1992.

Reisenleitner, Markus. "Habsburgische Höfe in der Frühen Neuzeit Entwicklungslinien und Forschungsprobleme." Opera historica 7 (1999): 97-114.

---. "Wege zum Adel." Frühneuzeit-info 1.1 (1990): 32.

Soja, Edward W. Postmetropolis: Critical Studies of Cities and Regions. Oxford: Blackwell, 2000.

Vocelka, Karl. Die Politische Propaganda Kaiser Rudolfs II. (1576-1612). Veröffentlichungen der Kommission für die Geschichte Österreichs; Bd. 9. Wien: Verlag der Österreichischen Akademie der Wissenschaften, 1981. 
---. “Du Bist Die Port Und Zir Alzeit, Befestigung Der Christenheit - Wien zwischen Grenzfestung und Residenzstadt im späten Mittelalter und in der Frühen Neuzeit." Metropolen Im Wandel. Zentralität in Ostmitteleuropa Vom Mittelalter Zur Neuzeit. Eds. E. Engel, K. Lambrecht and H. Nogossek. Berlin, 1995. 263-75. 